Studia nad Autorytaryzmem i Totalitaryzmem 43, nr 3

Wrocław 2021

https://doi.org/10.19195/2300-7249.43.3.19

\author{
MAŁGORZATA NIKLEWICZ-PIJACZYŃSKA \\ ORCID: 0000-0002-5305-4729 \\ Uniwersytet Wrocławski \\ malgorzata.niklewicz-pijaczyńska@uwr.edu.pl
}

\title{
Dyfuzja wiedzy technicznej w państwach autorytarnych — casus Białorusi
}

\author{
Slowa kluczowe: autorytaryzm, innowacje, patenty.

\section{DIFFUSION OF TECHNICAL KNOWLEDGE IN THE AUTHORITARIAN STATES: THE CASE OF BELARUS}

\begin{abstract}
The paper refers to the problem of knowledge diffusion and innovative activity of entities operating within the structures of authoritarian states. It is extremely important because it points to a specific paradox. On the one hand, authoritarian states try to participate in the global technology race; on the other, their strategy is based on the fundamental assumptions of authoritarianism, which automatically eliminates their chance of success in the area. Closure to external influences, monopolization of the economy, shaping the habits of imitative task performance, subordination to the superior interests of the state, and suppressing competition-based entrepreneurship reduce the innovative potential of authoritarian countries. This has a real impact on their low ranking in this area. The paper focuses on two aspects; firstly, its purpose is to determine to what extent Belarusian active innovative entities use the previously available technical knowledge in the solutions they have developed. Secondly, the article aims at identifying the scope and type of cooperation undertaken in the course of the innovation process they implement. In order to pursue the objectives, qualitative and quantitative research was carried out on the technical invention documentation, using the method of analysing the so-called patent citations. The conclusions of the research indicate that although the dynamics of the developing modern technology impose abandoning the traditional approach towards an ever wider opening of the inventive process to external sources, Belarus' innovation policy forces innovators to focus primarily on internal sources of knowledge and their own, strongly individualized resources.
\end{abstract}

Keywords: authoritarianism, innovations, patents. 


\section{Wprowadzenie}

Kraje zaliczane do grupy państw autorytarnych charakteryzują się zróżnicowanym poziomem innowacyjności. Wymienić można zarówno liderów innowacji, którzy wykorzystują nowoczesną formę autorytaryzmu do stymulowania postępu technologicznego, jak i kraje, dla których autorytaryzm stanowi specyficzną kotwicę uniemożliwiającą wybicie się na bardzo konkurencyjnym rynku technologii. Zróżnicowanie pozycji innowacyjnej nie jest zaskoczeniem, zależy ona bowiem od takich czynników, jak stopień zamknięcia na wpływy zewnętrzne, koncentracja środków na tworzeniu silnej władzy wykonawczej, egzekwowania bezwzględnego podporządkowania się obywateli przez kształtowanie nawyków odtwórczego wykonywania zadań i posłuszeństwa wobec autorytetów oraz tłumienia oddolnie stymulowanej przedsiębiorczości. Wiąże się to z tym, że autorytaryzm odrzuca podstawowe instytucje i procedury wpisujące się w rzeczywistość demokratyczną, na którą składają się między innymi postęp naukowo-techniczny oraz rozwiązania prawne zorientowane na kształtowanie rzeczywistości informacyjnej ${ }^{1}$. W tym kontekście interesującym przypadkiem jest balansująca między skansenem a nowoczesnością Białoruś - zaliczana do krajów autorytarnych, próbująca jednocześnie sprostać wyzwaniom technologicznego współczesnego świata. W oficjalnych publikacjach wewnętrznych Białoruś prezentowana jest jako kraj z ogromnym potencjałem innowacyjnym, wykorzystywanym w sposób niezwykle efektywny. Jednak według wskazań Global Innovation Index dla roku 2020 zajmuje ona dopiero 64 miejsce na 131 ujętych w nim państw świata, tuż za Armenią, Brazylią i Gruzją, a przed Tunezją, Arabią Saudyjską i Iranem. Wyniki wartości cząstkowych składających się na ostateczną pozycję innowacyjną Białorusi wskazują jej słabe i mocne strony. Do atutów należą zasoby kapitału ludzkiego i związany z nim potencjał badawczy, natomiast wśród aspektów, które wymagają gruntownego przewartościowania, znajdują się właściwie wszystkie pozostałe - działanie instytucji, jakość infrastruktury, funkcjonowanie rynku i konkurencji, warunki prowadzenia działalności gospodarczej oraz komercjalizacja wyników prowadzonych prac badawczych. Reasumując, nawet pobieżna analiza tych wartości pozwala stwierdzić, że potencjał innowacyjny Białorusi opiera się wyłącznie na kreatywnym czynniku ludzkim, który radzi sobie mimo niesprzyjających ku temu warunków² ${ }^{2}$.

Należy podkreślić, że komparatywna ocena innowacyjności państw zależna jest od wskaźników dobranych adekwatnie do wyznaczanych celów badawczych, dlatego może kształtować się w sposób zróżnicowany. Niemniej jednak w obszarze badań nad innowacyjnością istnieją wskaźniki obiektywne w tym sensie, że powtarzają się niezależnie od rodzaju zestawienia i są uznawane za akceptowaną

${ }^{1}$ A. Chodubski, Autorytaryzm w przestrzeni współczesnego życia politycznego, „Studia Politicae Universitatis Silesiensis" 17, 2016, s. 15.

2 www.wipo.int/edocs/pubdocs/en/wipo_pub_gii_2020.pdf, s. 224 (dostęp: 14.02.2021). 
jej miarę. Należy do nich wskaźnik uwzględniający liczbę patentów uzyskanych przez podmioty działające w danym kraju. Ze względu na swój uniwersalny charakter analiza patentów wykorzystana zostanie w niniejszej publikacji do oceny dyfuzji wiedzy technicznej, a tym samym oceny poziomu aktywności innowacyjnej Białorusi. Przyjęto, że na jej przebieg wpływ mają dwa czynniki, dyfuzja wiedzy technicznej oraz umiejętność kooperacji z podmiotami zewnętrznymi.

Na potrzeby artykułu wyznaczono dwa cele badawcze. Pierwszym z nich jest zbadanie, w jakim stopniu białoruskie podmioty aktywne innowacyjne wykorzystują udostępnioną wcześniej wiedzę techniczną w opracowanych przez siebie rozwiązaniach. Drugim - określenie stopnia i rodzaju kooperacji podejmowanej $\mathrm{w}$ trakcie realizowanego procesu innowacji.

Do ich realizacji wykorzystano dwie metody badawcze. Pierwsza z nich polega na kompleksowej analizie tak zwanych cytowań patentowych. Cytowania patentowe są to odwołania do wcześniejszych, znanych twórcom rozwiązań (czyli tak zwanej starej wiedzy), znajdujące się w dokumentacji patentowej zgłaszanych do ochrony nowych wynalazków. Druga opiera się na analizie ilościowej i jakościowej dokumentacji wynalazczej w zakresie podejmowanej przez uprawnionych współpracy. Przy opracowywaniu wyników korzystano z bazy dokumentacji patentowej Europejskiego Urzędu Patentowego. W badaniach uwzględniono patenty przyznane na rzecz białoruskich podmiotów w latach 2018-2020. Jest to okres odpowiadający tak zwanemu technologicznemu starzeniu się wiedzy.

\section{Regulacje prawa patentowego Białorusi}

Białoruskie ustawodawstwo patentowe ma stosunkowo niedługi rodowód. Kształtowanie nowoczesnego systemu ochrony własności intelektualnej rozpoczęto dopiero w roku 1992, powołując Państwowy Resort Patentowy i Zarząd Praw Autorskich i Pokrewnych działający przy Radzie Ministrów. Pierwszą ustawę z obszaru własności przemysłowej - wynalazków, wzorców przemysłowych oraz znaków towarowych — uchwalono w roku $1993^{3}$. Białoruś jest przy tym sygnatariuszem najważniejszych konwencji i umów międzynarodowych w zakresie ochrony własności intelektualnej, w tym przemysłowej. W roku 2004 dekretem Prezydenta przyjęto, że za ochronę praw własności intelektualnej odpowiedzialne jest Narodowe Centrum Własności Intelektualnej ${ }^{4}$. W roku 1998 uregulowano też status państwowych rzeczników patentowych. Są oni jedynymi dopuszczalnymi prawnie reprezentantami osób fizycznych i prawnych

\footnotetext{
3 https://www.ncip.by/en/o-centre/istoriya/ (dostęp: 15.02.2021).

4 Provisions on Secret Inventions, Utility Models, Industrial Designs (approved by Regulation of the Council of Ministers of the Republic of Belarus on July 2, 2003, No 900).
} 
zobligowanymi do podejmowania działań z zakresu ochrony oraz wykonywania praw własności przemysłowej ${ }^{5}$.

Dla efektywnego obrotu i ochrony własności intelektualnej powołano ponadto szereg instytucjonalnych organów, wśród których wymienić należy Państwowy Komitet ds. Nauki i Technologii Republiki Białoruś, Kolegium Sądowe Sądu Najwyższego ds. własności intelektualnej (jako instancja odwoławcza od decyzji Rady Apelacyjnej przy Komitecie Państwowym ds. Nauki i Technologii.), Republikańską Bibliotekę Naukowo-Techniczną oraz Białoruskie Stowarzyszenie Wynalazców i Racjonalizatorów. W kontekście poruszanego w artykule problemu warto wskazać zwłaszcza na dwa ostatnie: Republikańską Bibliotekę Naukowo-Techniczną, zajmującą się archiwizacją dokumentów patentowych, oraz Białoruskie Stowarzyszenie Wynalazców i Racjonalizatorów, skoncentrowane na działaniach związanych z aktywnością racjonalizatorską ${ }^{6}$.

Aktualnie obowiązującym dokumentem regulującym kwestie własności przemysłowej jest uchwalona 6 grudnia 2002 roku ustawa Patenty na wynalazki, wzory użytkowe i wzory przemysłowe ${ }^{7}$. Zgodnie $\mathrm{z}$ jej postanowieniami ochrona prawna przysługuje na wynalazki z dowolnej dziedziny techniki o charakterze nowatorskim, cechujące się poziomem wynalazczym i znajdujące zastosowanie w przemyśle. Muszą one zatem mieć określony walor użyteczności, potencjał gospodarczy $^{8}$. Wniosek o udzielenie patentu należy składać w Narodowym Centrum Własności Intelektualnej. Zgłoszenie oprócz zgodności z wytycznymi wymienionej ustawy powinno spełniać wymogi zawarte w Regulaminie w sprawie przepisów dotyczących procedury sporządzania wniosków o patenty na wynalaz$\mathrm{ki}$, ich badania i podejmowania decyzji ${ }^{9}$.

\section{Dyfuzja wiedzy technicznej, sposoby pomiaru}

Jednym z najważniejszych czynników kształtujących poziom innowacyjności jest dyfuzja wiedzy, w szczególności wiedzy technicznej. W literaturze przedmiotu wiedza techniczna określana jest jako pewien zasób wiarygodnych informacji

5 Postanowienie Rady Ministrów z 11 marca 1998 r., Regulamin działalności rzeczników patentowych (nr 379).

6 www.google.com/url? sa=t\&rct=j\&q=\&esrc=s\&source=web\& $\mathrm{cd}=\&$ ved $=2 \mathrm{ahUKEwj} 5 \mathrm{vZa}$ Uy_DuAhUh-yoKHe8cCnsQFjABegQIAxAC\&url=https\%3A\%2F\%2Fbelarus.trade.gov.pl\%2Fpl\%2Fprawny-samouczek\%2Fochrona-wlasnosci\%2F52\%2Cjak-chronic-patenty-i-znaki-towaro we.html.pdf\&usg=AOvVaw29W25iYFt3rO3ROm5EVCNp (dostęp: 17.02.2021).

7 Law of the Republic of Belarus on December 16, 2002 (No 160-Z), Patents for Inventions, Utility Models and Industrial Designs.

8 Ibidem.

9 Rozporządzenie Rady Ministrów Republiki Białorusi z 2 lutego 2011 r. (nr 119), uchwała Państwowego Komitetu ds. Nauki i Technologii Republiki Białorusi o ustalaniu form dokumentów dla patentów na wynalazki, z 5 czerwca 2018 r. (nr 16). 
z zakresu techniki oraz umiejętność ich wykorzystywania w praktyce ${ }^{10}$. Składają się na nią między innymi dane techniczne, formuły, normy, specyfikacje, procesy, metody czy zbiory kodów. Tak rozumiana wiedza jest zarówno przedmiotem, jak i efektem transferu informacji o ścisłym, inżynieryjnym charakterze, zachodzącym $w$ trakcie prowadzonych prac badawczych oraz rozwojowych. Do wiedzy technicznej zaliczamy przykładowo wiedzę ekspercką na temat obsługi, konserwacji, użytkowania czy zastosowania produktu. Jej kodyfikacja odbywa się przez zapisanie określonych formuł, projektów, rysunków, procedur i metod, stanowiąc efekt nagromadzonych umiejętności i doświadczeń ${ }^{11}$. W naukach z zakresu zarządzania określana jest jako ten rodzaj wiedzy, który pozwala odpowiedzieć na pytanie: jak? W rozumieniu wąskim wiedza techniczna utożsamiana jest z pojęciem wynalazku (nowatorskim, nieoczywistym rozwiązaniem technicznym znajdującym zastosowanie w przemyśle). Dyfuzja tak rozumianej wiedzy technicznej jest procesem rozprzestrzeniania się występującym wówczas, gdy po pierwszym udanym zastosowaniu nowego rozwiązania następuje jej przyswojenie przez inne podmioty oraz kreatywne wykorzystanie do tworzenia nowej wiedzy. Oznacza ona zatem proces traktowania istniejących rozwiązań jako podstawy do ich dalszej modyfikacji i kreowania nowych koncepcji technicznych. Tak rozumiana dyfuzja określana jest mianem aktywnej — w przeciwieństwie do dyfuzji biernej, polegającej jedynie na jej przyswojeniu bez efektu w postaci twórczej ekspresji. Należy zauważyć, że w literaturze przedmiotu pojawiają się zróżnicowane modele dyfuzji wiedzy powiązane koncepcyjnie z kontekstem prowadzonych badań. Ich obszerną analizę odnaleźć można w opracowaniach P. Geroskiego i C. Waltersa $^{12}$, V. Mahajanai, R.A. Petersona ${ }^{13}$ oraz polskich badaczy, między innymi S.M. Kota, A. Karskiej i K. Zająca ${ }^{14}$, Z. Matkowskiego i M. Próchniaka ${ }^{15}$ oraz

10 M. Goliński, M. Szafrański, Wiedza techniczna jako kluczowy czynnik rozwoju innowacyjności, „Zeszyty Naukowe Uniwersytetu Szczecińskiego. Ekonomiczne Problemy Usług” 2009, nr 45. „Nowoczesna Administracja Publiczna”, s. 195-204.

${ }^{11}$ Manual on Technology Transfer Negotiation, United Nations Industrial Development Organization (A Reference for Policy-makers and Practitioners on Technology Transfer), United Nations Industrial Development Organization, Vienna, Austria, 1996; Licensing Guide for Developing Countries, World Intellectual Property Organization (WIPO), Geneva, 1977; “TRIPS: Agreement on Trade-Related Aspects of Intellectual Property Rights (1995), Section 7: Protection of Undisclosed Information, Article 39(2)". wto.org. World Trade Organization. Archived from the original on 2017-01-20. Retrieved 2019-06-20.

12 P. Geroski, C.F. Walters, Innovative activity over the business cycle, „Economic Journal" 105, 1995, nr 431, s. 916-928.

13 V. Mahajan, R.A. Peterson, Models for Innovation Diffusion, Thousand Oaks 1985.

14 A. Karska, S.M. Kot, K. Zając, Matematyczne modele procesów dyfuzji innowacji, Warszawa 1993.

15 Z. Matkowski, M. Próchniak, R. Rapacki, Scenariusze realnej konwergencji w Unii Europejskiej-kraje EŚW aUE-15, [w:] Polska w Unii Europejskiej i globalnej gospodarce, red. M. Gorynia, S. Rudolf, Warszawa 2014. 
S. Kubielasa ${ }^{16}$. Prowadzone w tym obszarze badania koncentrują się na fundamentalnych dla przebiegu dyfuzji wiedzy czynnikach, jak: bliskość geograficzna, wpływ bezpośrednich inwestycji bezpośrednich, asymetria informacji, różnice między krajami bogatymi a biednymi, adekwatność technologii do kwalifikacji siły roboczej, komplementarność działalności prorozwojowej, niedoskonałość instytucji, nieskuteczność ochrony praw własności ${ }^{17}$.

Jednym z czynników warunkujących przebieg procesu aktywnej dyfuzji wiedzy jest możliwość dostępu do zdywersyfikowanych jej źródeł. Należą do nich między innymi zasoby archiwizowanej informacji patentowej oraz współpraca z podmiotami trzecimi. Wspomniane źródła wiedzy różnią się między sobą tym, że w kooperacji z podmiotami zewnętrznymi przedsiębiorstwo uzyskuje dostęp do wiedzy zarówno jawnej, jak i nieformalnej, ale wymagana jest przy tym interakcja o charakterze bezpośrednim. Natomiast wykorzystanie archiwów baz patentowych, choć eliminuje konieczność kontaktu z posiadaczem określonych informacji, daje dostęp jedynie do tych, które zdecydował się on udostępnić do wiadomości publicznej, czyli wiedzy jawnej. Wspólnych dla nich mianownikiem jest okoliczność, że w każdym przypadku zachodzi proces pozyskania wiedzy w ramach obiegu sieciowego.

\section{Wyniki badań}

Przeprowadzona na potrzeby badań analiza dokumentacji technicznej opatentowanych wynalazków pokazała, że wśród białoruskich podmiotów podejmujących aktywność wynalazczą zdecydowany prym wiodą uczelnie oraz ośrodki badawczo-naukowe. Stanowią one $80 \%$ ogółu podmiotów aktywnych w tym obszarze. W 19\% wynalazcami były osoby fizyczne, tylko w jednym przypadku jako podmiot uprawniony wskazana została firma prywatna.

Jednak mimo że białoruskie uczelnie licznie podejmują aktywność wynalazczą, rzadko decydują się na jakąkolwiek formę współpracy w tym obszarze, co sprawia, że aż w $80 \%$ proces innowacji był mocno zindywidualizowany. Natomiast gdy współpraca była podejmowana, to dotyczyła kooperacji między uczelniami białoruskimi (20\%). Tylko przy opracowywaniu jednego wynalazku współpracowały z sobą uczelnie z różnych regionów geograficznych — białoruska oraz chińska. Także współpraca między uczelnią a osobą fizyczną była jednostkowa (rys. 1).

16 S. Kubielas, Innowacje i luka technologiczna w gospodarce globalnej opartej na wiedzy. Strukturalne i makroekonomiczne uwarunkowania, Warszawa 2009.

17 M. Niklewicz-Pijaczyńska, System patentowy w gospodarowaniu wiedza. Ekonomia wiedzy technicznej skodyfikowanej, Wrocław 2019, s. 121. 


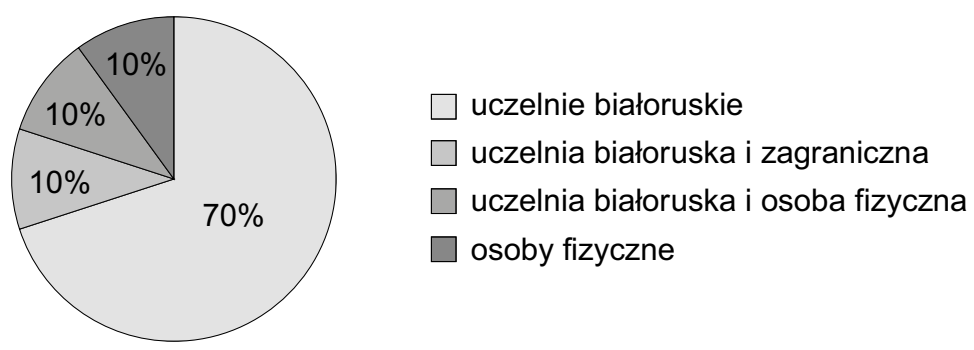

Rys. 1. Formy współpracy w procesie innowacji

Źródło: opracowanie własne.

Przedstawione wyniki wskazują, że opracowanie nowego rozwiązania opiera się na zasobach własnych, a tym samym koncentracji na wewnętrznych źródłach wiedzy i słabej jej dyfuzji. Podobnie jest w odniesieniu do aktywności wynalazczej podmiotów fizycznych, jest ona bardzo zindywidualizowana, jedynie w jednym przypadku, przy opracowaniu nowego rozwiązania, współpracowały z sobą cztery osoby, wszystkie będące obywatelami Białorusi. W przeprowadzonych badaniach nie udało się natomiast zidentyfikować żadnego przypadku współpracy między ośrodkami akademickimi a przedsiębiorcami ani też między przedsiębiorcami a indywidualnymi wynalazcami. Oznacza to, że białoruskie podmioty aktywne wynalazczo koncentrują się przede wszystkim na wewnętrznych zasobach wiedzy, w tym potencjale pracowników, własnej infrastrukturze i indywidualnej kreatywności, a przypadki kooperacji w tym obszarze mają charakter sporadyczny i statystycznie pomijalny.

Przeprowadzona następnie analiza cytowań patentowych, czyli odwołań twórców wynalazku do wiedzy poprzedników, pozwoliła na weryfikację wskazanych wniosków dotyczących intensywności wykorzystania wiedzy zewnętrznej, na poziomie ściśle doprecyzowanej specjalistycznej wiedzy w sposób merytoryczny powiązanej z opatentowanym wynalazkiem. Cytowania takie pojawiły się w 75\% analizowanych dokumentów. Co charakterystyczne, w opisie wynalazków powoływano przede wszystkim rozwiązania innych białoruskich podmiotów. Cytowania tego typu pojawiły się w $29 \%$ analizowanych przypadków. Na drugim miejscu plasowały się cytowania patentów rosyjskich. Odchyleniem od tak zarysowanego trendu były powołania na patenty amerykańskie - 16\% ogółu powołań. Szczegółowy rozkład pozostałych cytowań znajduje się na rys. 2.

Wśród pozostałych cytowań umieszczonych w opisach wynalazków znalazły się powołania na rozwiązania techniczne zgłoszone do ochrony w Wielkiej Brytanii, Chinach, byłym Związku Radzieckim, Euroazjatyckiej Organizacji Patentowej, Europejskim Systemie Patentowym oraz Światowej Organizacji Własności Intelektualnej. 


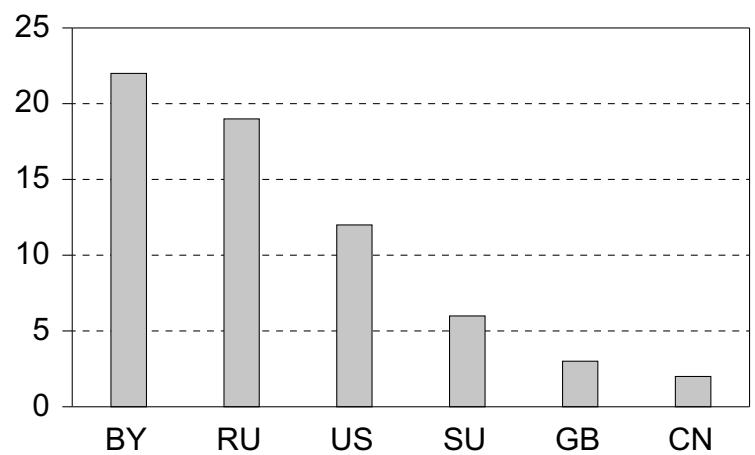

Rys. 2. Cytowania patentowe według kraju Źródło: opracowanie własne.

Te wyniki potwierdzają mocną koncentrację na wewnętrznych zasobach wiedzy, tym razem scharakteryzowaną przez identyfikację geograficzną. Oznacza to jednocześnie, że warunkiem powodzenia podejmowanej aktywności innowacyjnej białoruskich wynalazców, czy to podmiotów fizycznych, czy ośrodków akademickich, jest bliskość geograficzna w dostępie do specjalistycznej, inżynieryjnej wiedzy.

\section{Zakończenie}

Wyniki badań empirycznych dotyczące częstotliwości podejmowanej w procesie innowacji współpracy badawczo-rozwojowej oraz stopnia wykorzystywania wiedzy zewnętrznej przez białoruskich wynalazców wskazują na znaczną koncentrację geograficzną w obu analizowanych aspektach. Po pierwsze, zidentyfikowane cytowania patentowe odnoszą się przede wszystkim do rozwiązań twórców białoruskich oraz podmiotów rosyjskich. Po drugie, współpraca badawczo-rozwojowa ma charakter incydentalny i jeśli już jest podejmowana, ogranicza się do kooperacji między podmiotami białoruskimi. Można w tym kontekście przyjąć, że owe wnioski będą reprezentatywne dla większości krajów autorytarnych, których fundamentalne założenia oparte są na samowystarczalności, koncentracji na wewnętrznych źródłach innowacji oraz centralizacji wysiłków badawczych. Teza ta w każdym przypadku wymaga jednak analogicznej weryfikacji empirycznej. 


\section{Bibliografia}

Chodubski A., Autorytaryzm w przestrzeni wspótczesnego życia politycznego, „Studia Politicae Universitatis Silesiensis" 17, 2016.

Geroski P., Walters C.F., Innovative Activity Over the Business Cycle, „Economic Journal” 105, 1995, nr 431.

Goliński M., Szafrański M., Wiedza techniczna jako kluczowy czynnik rozwoju innowacyjności, „Zeszyty Naukowe Uniwersytetu Szczecińskiego. Ekonomiczne Problemy Usług” 2009, nr 45. „Nowoczesna Administracja Publiczna”.

Karska A., Kot S.M., Zając K., Matematyczne modele procesów dyfuzji innowacji, Warszawa 1993.

Kubielas S., Innowacje i luka technologiczna w gospodarce globalnej opartej na wiedzy. Strukturalne i makroekonomiczne uwarunkowania, Warszawa 2009.

Mahajan V., Peterson R.A., Models for Innovation Diffusion, Thousand Oaks 1985.

Matkowski Z., Próchniak M., Rapacki R., Scenariusze realnej konwergencji w Unii Europejskiejkraje EŚW a UE-15, [w:] Polska w Unii Europejskiej i globalnej gospodarce, red. M. Gorynia, S. Rudolf, Warszawa 2014.

Niklewicz-Pijaczyńska M., System patentowy w gospodarowaniu wiedza. Ekonomia wiedzy technicznej skodyfikowanej, Wrocław 2019.

Rozporządzenie Rady Ministrów Republiki Białorusi z 31 maja 2004 r. (nr 641), https://wipolex. wipo.int/en/text/230235.

Rozporządzenie Rady Ministrów Republiki Białorusi z 2 lutego 2011 r. (nr 119), https://wipolex. wipo.int/en/text/10081.

Postanowienie Rady Ministrów z 11 marca 1998 r. Regulamin działalności rzeczników patentowych (nr 379), https://www.wipo.int/madrid/en/legal_texts/laws.jsp.

Uchwała Państwowego Komitetu ds. Nauki i Technologii Republiki Białorusi, O ustalaniu form dokumentów dla patentów na wynalazki, z 5 czerwca 2018 r. (nr 16), https://wipolex.wipo.int/ en/legislation/details/18554.

Law of the Republic of Belarus on December 16, 2002 (No 160-Z 2016-06-15), On Patents for Inventions, Utility Models and Industrial Designs.

Licensing Guide for Developing Countries, World Intellectual Property Organization (WIPO), Geneva, 1977, ISBN 92-805-0395-2.

Manual on Technology Transfer Negotiation, United Nations Industrial Development Organization (A Reference for Policy-makers and Practitioners on Technology Transfer), United Nations Industrial Development Organization, Vienna, Austria (1996) ISBN 92-1-106302-7.

Provisions on Secret Inventions, Utility Models, Industrial Designs (approved by Regulation of the Council of Ministers of the Republic of Belarus on July 2, 2003 (No 900).

TRIPS: Agreement on Trade-Related Aspects of Intellectual Property Rights (1995), Section 7: Protection of Undisclosed Information, Article 39(2), World Trade Organization. Archived from the original on 2017-01-20.

https://www.ncip.by/en/o-centre/istoriya.

www.google.com/url?sa=t\&rct=j\&q=\&esrc=s\&source=web\&cd=\&ved=2ahUKEwj5vZaUy_DuAhUh-yoKHe8cCnsQFjABegQIAxAC\&url=https\%3A\%2F\%2Fbelarus.trade.gov.pl\%2Fpl\%2Fprawny-samouczek\%2Fochrona-wlasnosci\%2F52\%2Cjak-chronic-patenty-i-znaki-towarowe.html.pdf\&usg=AOvVaw29W25iYFt3rO3ROm5EVCNp.

www.wipo.int/edocs/pubdocs/en/wipo_pub_gii_2020.pdf. 